\title{
Influence of Micro-Encapsulated Probiotic Lactobacillus acidophilus R0052 on the Characteristics of Plain Yogurt
}

\author{
Edwin Noland ${ }^{1}$, Kayanush J. Aryana ${ }^{1,2^{*}}$ \\ ${ }^{1}$ School of Animal Science, Louisiana State University Agricultural Center, Baton Rouge, USA \\ ${ }^{2}$ Department of Food Science, Louisiana State University Agricultural Center, Baton Rouge, USA \\ Email: *karyana@agcenter.lsu.edu
}

Received July 1, 2012; revised July 30, 2012; accepted August 10, 2012

\begin{abstract}
Micro-encapsulation is a method of providing probiotic living cells with a physical barrier against adverse environmental conditions. Lactobacillus acidophilus is one of the most effective forms of probiotic bacteria and is commercially available as pure culture and encapsulated form. It is not clear whether the use of micro-encapsulated $L$. acidophilus will result in yogurt of a better quality compared to non micro-encapsulated $L$. acidophilus. The objective was to determine the influence of micro-encapsulated $L$. acidophilus on the characteristics of fat free plain yogurt. Yogurt mixes were pasteurized and at $37^{\circ} \mathrm{C}$ were inoculated with Streptococcus thermophilus, Lactobacillus delbrueckii subsp. bulgaricus and micro-encapsulated $L$. acidophilus R0052 or non micro-encapsulated L. acidophilus R0052. Yogurt manufacture was replicated three times. Yogurts with micro-encapsulated L. acidophilus R0052 had significantly $(P<$ 0.05) higher flavor scores, compared to yogurts with non micro-encapsulated L. acidophilus R0052. The L. acidophilus counts, apparent viscosity, $\mathrm{pH}$ and syneresis, of the yogurts with micro-encapsulated L. acidophilus R0052 were not significantly $(P<0.05)$ different from those of the yogurts with non micro-encapsulated $L$. acidophilus R0052. Use of micro-encapsulated $L$. acidophilus R0052 resulted in better tasting yogurts probably because of the taste imparted by the trace amounts of the micro-encapsulating material.
\end{abstract}

Keywords: Probiotic; Micro-Encapsulation; Fermented; Cultured; Shelf Life

\section{Introduction}

Probiotics are defined as "live microorganisms which when administered in adequate amounts confer health benefits to host" [1]. There has been an increasing interest in the role of probiotic bacteria in human health. Health advantages associated with the probiotic intake include alleviation of symptoms of lactose malabsorption, increase in natural resistance to infectious diseases of the intestinal tract, suppression of cancer, reduction in serum cholesterol concentrations, improved digestion, and stimulation of gastrointestinal immunity [2]. It is generally accepted that successful delivery and colonization of viable probiotic cells in the intestine are essential for probiotics to be efficacious [3]. As a guide, the Intl. Dairy Federation has recommended that the bacteria be viable and abundant in the product and be present at a population of at least $10^{7}$ colony-forming units $(\mathrm{CFU}) / \mathrm{g}$ until the date of consumption [4]. However, studies indicate that the bacteria may not survive in sufficient numbers when incorporated into dairy products and during their passage through the gastrointestinal tract [5]. Sev-

${ }^{*}$ Corresponding author. eral factors influence the survival and colonization of these bacteria, including resistance to low $\mathrm{pH}$, bile acids, and digestive enzymes [1].

Micro-encapsulation is a method of providing probiotic living cells with a physical barrier against adverse environmental conditions [6]. Micro-encapsulation helps to protect the beneficial bacteria from destruction by stomach acid for example and thereby enhances its viability. Several methods of micro-encapsulation of probiotic bacteria include spray drying, extrusion, emulsion and phase separation [7]. The most commonly reported micro-encapsulation procedure is based on the calciumalginate gel capsule formation, and materials for microencapsulation include alginates, kappa-carrageenan, gellan gum, gelatin and starch [7].

The two culture bacteria Streptococcus thermophilus and Lactobacillus bulgaricus are required in yogurt manufacture according to the legal description of yogurt [8]. Lactobacillus acidophilus is one of the most effective forms of probiotic bacteria. Health benefits of Lactobacillus acidophilus include reduction in occurrence of diarrhea in humans, enhancement of the immune system, reduction in cholesterol and improved symptoms of lac- 
tose intolerance [9] and antitumor effects [10]. Use of $L$. acidophilus in rats reduced the number of colon cancer cells in a dose dependent manner [11]. Lactobacillus acidophilus is widely used as an adjunct culture in yogurt manufacture in the United States [12] and these $L$. acidophilus cells are in the non micro-encapsulated form. It is not clear if the use of micro-encapsulated L. acidophilus cells would result in a yogurt of a better quality compared to non micro-encapsulated L. acidophilus. The objective was to study the influence of micro-encapsulated L. acidophilus on the characteristics of fat free plain yogurt.

\section{Materials and Methods}

\subsection{Yogurt Manufacture}

Yogurts were manufactured using standard procedure [13, 14] with slight alteration. Yogurt mixes were homogenized, pasteurized and temperature lowered to $40^{\circ} \mathrm{C}$ and inoculated with yogurt culture bacteria Streptococcus thermophilus and Lactobacillus delbrueckii ssp. bulgaricus (Chr. Hansen Milwaukee, WI) at a constant rate of 20 g per gallon (3.785 L). Encapsulated L. acidophilus R0052 or non encapsulated L. acidophilus R0052 (Institut Rosell-Lallemand Inc. Montreal, Quebec, Canada) were individually incorporated in the yogurt mixes at the same rate of $20 \mathrm{~g}$ per $3.785 \mathrm{~L}$. Inoculated yogurt mixes were poured into $355 \mathrm{~mL}$ containers (Reynolds RDC212Del-Pak Combo-Pak, Alcoa, Inc., Pittsburgh, PA) and incubated at $40^{\circ} \mathrm{C}$ to $\mathrm{pH} 4.5$ before cooling to $4^{\circ} \mathrm{C}$. Samples were stored at $4^{\circ} \mathrm{C}$ until analyzed. Product manufacture was replicated three times.

\subsection{Lactobacillus acidophilus Enumerations}

Counts of $L$. acidophilus were enumerated as reported earlier [15] but with modifications. The appropriate amount of distilled water was added to a $500 \mathrm{~mL}$ or $1 \mathrm{~L}$ graduated cylinder. MRS base medium without dextrose was prepared by weighing the appropriate proportion of $10.0 \mathrm{~g}$ of proteose peptone \#3 (United States Biological, Swampscott, MA), 10.0 g of beef extract (Becton, Dickinson and Co., Sparks, MD), 5.0 g of yeast extract (Becton, Dickinson and Co., Sparks, MD), $1.0 \mathrm{~g}$ of polysorbate 80 (Tween 80) (Sigma-Aldrich Inc., St. Louis, MO), $2.0 \mathrm{~g}$ of ammonium citrate (Fisher Scientific, Fair Lawn, NJ), 5.0 g of sodium acetate, anhydrous (EMD Chemicals Inc., Gibbstown, NJ), 0.1 g of magnesium sulfate, anhydrous (EMD Chemicals Inc., Gibbstown, NJ), 0.05 g of manganese sulfate, monohydrate (Sigma-Aldrich Inc., St. Louis, MO), $2.0 \mathrm{~g}$ of dipotassium phosphate (Fisher Scientific, Fair Lawn, NJ), and 15.0 g of agar (EMD Chemicals Inc., Gibbstown, NJ) and diluting these ingredients to the appropriate proportion of $1 \mathrm{~L}$ with distilled water. This mixture was heated to boiling with agitation before autoclaving at $121^{\circ} \mathrm{C}$ for $15 \mathrm{~min}$. A $10 \%(\mathrm{w} / \mathrm{v})$ sorbitol (EMD Chemicals Inc., Gibbstown, NJ) solution was prepared and filtered sterilized with Nalgene Membrane Filter Units (Nalge Co., Rochester, NY), and the appropriate amount of this solution was aseptically added to the MRS base medium to form a $10 \%$ sorbitol solution (final concentration of $1 \%$ sorbitol i.e. $1 \mathrm{~g}$ sorbitol in 100 $\mathrm{mL}$ of final medium) and 90\% MRS base medium mixture immediately before pouring the plates. The appropriate dilutions of yogurt were made with $99 \mathrm{~mL}$ of sterilized peptone (or sterilized Butterfield buffer in prefilled dilution bottles (Weber Scientific, Hamilton, NJ)). The pour plate method with this MRS-sorbitol agar was performed. Petri dishes were placed in BBL GasPaks (BBL, Becton, Dickinson and Co., Cockeysville, MD) and incubated anaerobically at $37^{\circ} \mathrm{C}$ for $72 \mathrm{~h}$. A Quebec Darkfield Colony Counter (Leica Inc., Buffalo, NY) was used to assist in enumerating the colonies.

\section{3. $\mathrm{pH}$}

The $\mathrm{pH}$ of the yogurts at $4^{\circ} \mathrm{C}$ was determined using an UltraBasic Benchtop pH Meter (Denver Instrument Company, Arvada, CO, USA) calibrated using commercial $\mathrm{pH}$ 4.00 and 7.00 buffer solutions.

\subsection{Apparent Viscosity}

The apparent viscosities were determined at $4^{\circ} \mathrm{C}$ using a Brookfield DV II+ viscometer (Brookfield Engineering Lab Inc., Stoughton, MA, USA) with a helipath stand. A $\mathrm{T}$-C spindle was used at $10 \mathrm{rpm}$. The data were acquired using the Wingather ${ }^{\circledR}$ software (Brookfield Engineering Lab Inc., Stoughton, MA, USA). One hundred data points were averaged per sample.

\subsection{Syneresis}

The release of whey from the yogurt samples was measured by inverting a $300 \mathrm{~g}$ sample at $4^{\circ} \mathrm{C}$ on a fine cheese cloth placed on top of a funnel. The quantity of whey collected in a graduated cylinder after $2 \mathrm{~h}$ of drainage was used as an index of syneresis.

\subsection{Sensory Evaluation}

Sensory evaluations were conducted using a seven member experienced panel. The panelists had over 4 months of training in judging yogurts. Samples were provided to panelists in three digit random number coded plastic cups. Water was provided to panelists to rinse their palate between samples. Panelists were instructed not to talk during the sensory evaluation. The official American Dairy Science Association intercollegiate dairy products evaluation contest score card was used to evaluate flavor on a 1 
to 10 point scale $(10=$ no criticism $)$.

\subsection{Statistical Analysis}

Data were analyzed by Analysis of Variance using Proc Mixed of the Statistical Analysis Systems. Significant differences between means were determined using Fisher's protected Least Significant Difference test. Significant differences were determined at $\alpha=0.05$.

\section{Results and Discussion}

The $\mathrm{pH}$ values are reported in Table 1. At week 5 the $\mathrm{pH}$ was an average of $4.4 \mathrm{pH}$ units. There were no differences in $\mathrm{pH}$ between the yogurts made using the micro-encapsulated and non micro-encapsulated bacteria. Micro-encapsulation being just a physical coating on the microorganism [7] and did not play a role in influencing product $\mathrm{pH}$.

Lactobacillus acidophilus counts were converted to $\log _{10}$ scale before the data were analyzed by SAS. The $L$. acidophilus counts are reported in Table 1. There were no differences in counts of the micro-encapsulated and non micro-encapsulated bacteria. The reason for the micro-encapsulation of $L$. acidophilus was to increase bacterial viability by protection against the acidic environment of the stomach having $\mathrm{pH}$ 's between $1.50-2.00$. Viability of bacteria in yogurt declines when the yogurt $\mathrm{pH}$ drops below 4.3 [16] hence since the $\mathrm{pH}$ of the yogurts at 5 weeks was 4.4 there were no drop in counts of non micro-encapsulated $L$. acidophilus compared to the micro-encapsulated $L$. acidophilus.

Syneresis is the serum released from the product. The syneresis values are presented in Table 2 . There were no differences between the two different types of yogurts. The microencapsulating material is a fatty acid and does not play a role in binding water hence did not influence syneresis.

Apparent viscosity values are reported in Table 2 . There were no differences in apparent viscosity. The $L$. acidophilus was used in trace amounts of $0.1 \% \mathrm{v} / \mathrm{v}$ of yogurt mix, hence the microencapsulating material was also present in trace amounts. Micro-encapsulating material can be a starch [7] which would have a partial thickening effect on the yogurt. The micro-encapsulating material in the present study was a fatty acid hence there was no change in viscosity of the yogurts.

Flavor scores are reported in Table 3. Yogurts with micro-encapsulated bacteria had significantly higher flavor scores compared to yogurts with non encapsulated bacteria. Microencapsulating material was a fatty acid which probably was the reason for making the fat free plain yogurts taste different.

\section{Conclusion}

Use of micro-encapsulated $L$. acidophilus improved product flavor but did not have any effect on the remaining characteristics studied. Product flavor is an important

Table 1. Mean \pm SE of $\mathrm{pH}$ values and $L$. acidophilus counts of the various yogurts over a storage period of 5 weeks.

\begin{tabular}{|c|c|c|c|c|c|c|}
\hline \multirow[t]{2}{*}{ Treatments } & \multicolumn{3}{|c|}{$\mathrm{pH}$ at weeks } & \multicolumn{3}{|c|}{ L. acidophilus counts $(\log \mathrm{cfu} / \mathrm{mL})$ at weeks } \\
\hline & 1 & 3 & 5 & 1 & 3 & 5 \\
\hline Micro-Encapsulated & $4.55 \pm 0.09^{\mathrm{A}}$ & $4.48 \pm 0.03^{\mathrm{A}}$ & $4.41 \pm 0.11^{\mathrm{A}}$ & $7.87 \pm 0.18^{\mathrm{A}}$ & $7.56 \pm 0.19^{\mathrm{A}}$ & $7.07 \pm 0.10^{\mathrm{A}}$ \\
\hline Non Micro-Encapsulated & $4.52 \pm 0.03^{\mathrm{A}}$ & $4.43 \pm 0.09^{\mathrm{A}}$ & $4.40 \pm 0.07^{\mathrm{A}}$ & $7.86 \pm 0.29^{\mathrm{A}}$ & $7.52 \pm 0.28^{\mathrm{A}}$ & $7.05 \pm 0.16^{\mathrm{A}}$ \\
\hline
\end{tabular}

${ }^{\mathrm{A}}$ Means in each column with the same letter did not differ significantly $(\mathrm{P}<0.05)$.

Table 2. Mean \pm SE of syneresis and apparent viscosity of the various yogurts over a storage period of 5 weeks.

\begin{tabular}{ccccccc}
\hline Treatments & \multicolumn{3}{c}{ Syneresis $(\mathrm{mL})$ at weeks } & \multicolumn{3}{c}{ Apparent viscosity $\left(\times 10^{4} \mathrm{cP}\right)$ at weeks } \\
\hline & 1 & 3 & 5 & 1 & 3 & 5 \\
Micro-encapsulated & $139.3 \pm 8.1^{\mathrm{A}}$ & $123.7 \pm 9.8^{\mathrm{A}}$ & $119.3 \pm 6.4^{\mathrm{A}}$ & $3.58 \pm 0.08^{\mathrm{A}}$ & $3.68 \pm 0.20^{\mathrm{A}}$ & $2.22 \pm 0.05^{\mathrm{A}}$ \\
Non Micro-Encapsulated & $140.7 \pm 11.9^{\mathrm{A}}$ & $125.7 \pm 5.1^{\mathrm{A}}$ & $121.7 \pm 5.8^{\mathrm{A}}$ & $3.64 \pm 0.16^{\mathrm{A}}$ & $3.73 \pm 0.30^{\mathrm{A}}$ & $2.25 \pm 0.19^{\mathrm{A}}$ \\
\hline
\end{tabular}

${ }^{\mathrm{A}}$ Means in each column with the same letter did not differ significantly $(P<0.05)$.

Table 3. Mean \pm SE of flavor scores of the various yogurts over a storage period of 5 weeks.

\begin{tabular}{cccc}
\hline Treatments & \multicolumn{3}{c}{ Flavor scores at weeks } \\
\hline & 1 & 3 & 5 \\
Micro-encapsulated & $7.53 \pm 0.50^{\mathrm{A}}$ & $7.69 \pm 0.53^{\mathrm{A}}$ & $7.67 \pm 0.51^{\mathrm{A}}$ \\
Non Micro-Encapsulated & $7.00 \pm 0.10^{\mathrm{B}}$ & $7.10 \pm 0.15^{\mathrm{B}}$ & $7.13 \pm 0.15^{\mathrm{B}}$ \\
\hline
\end{tabular}

\footnotetext{
${ }^{\mathrm{A}, \mathrm{B}}$ Means in each column with the same letter did not differ significantly $(\mathrm{P}<0.05)$.
} 
characteristic hence the use of micro-encapsulated bacteria should be considered in yogurt manufacture.

\section{REFERENCES}

[1] G. G Reid, M. E. Sanders and H. R. Gaskins "New Scientific Paradigms for Probiotics and Prebiotics," Journal of Clinical Gastroenterology, Vol. 37, No. 2, 2003, pp. 105118. doi:10.1097/00004836-200308000-00004

[2] K. Kailasapathy and J. C. Chin, "Survival and Therapeutic Potential of Probiotics Organisms with Reference to Lactobacillus acidophilus and Bifidobacterium spp," Immunology and Cell Biology, Vol. 78, No. 1, 2000, pp. 8088. doi:10.1046/j.1440-1711.2000.00886.x

[3] P. L. Conway, "Selection Criteria for Probiotic Microorganisms," Asia Pacific Journal of Clinical Nutrition, Vol. 5, 1996, pp. 10-14.

[4] A. C. Ouwehand and S. J. Salminen, 1998. "The Health Effects of Cultured Milk Products with Viable and NonViable Bacteria,” International Dairy Journal, Vol. 8, No. 9, pp. 749-758. doi:10.1016/S0958-6946(98)00114-9

[5] R. I. Dave and N. P. Shah, "Evaluation of Media for Selective Enumeration of Streptococcus, Lactobacillus delbrueckii spp. bulgaricus, Lactobacillus acidophilus, and Bifidobacteria," Journal of Dairy Science, Vol. 79, No. 9, 1996, pp. 1529-1536. doi:10.3168/jds.S0022-0302(96)76513-X

[6] W. Krasaekoopt, B. Bhandari and H. Deeth, "Evaluation of Encapsulation Techniques of Probiotics for Yoghurt: A Review," International Dairy Journal, Vol. 13, No. 1, 2003, pp. 3-13. doi:10.1016/S0958-6946(02)00155-3

[7] K. Sultana, G. Godward, N. Reynolds, R. Arumugaswamy, P. Peiris and K. Kailasapathy, "Encapsulation of Probiotic Bacteria with Alginate-Starch and Evaluation of Survival in Simulated Gastrointestinal Conditions in Yogurt," International Journal of Food Microbiology, Vol.
62, No. 1-2, 2000, pp. 47-55.

[8] US Food and Drug Administration, "Requirements for Specific Standardized Milk and Cream: Yogurt,” 2009. http://www.accessdata.fda.gov/scripts/cdrh/cfdocs/cfcfr/C FRSearch.cfm?fr=131.200

[9] M. E. Sanders, "Consideration for Use of Probiotic Bacteria to Modulate Human Health,” Journal of Nutrition, Vol. 130, No. 2S, 2000, pp. 384S-390S.

[10] Goldin and Gorbach, "The Effect of Milk and Lactobacillus Feeding in Human Intestinal Bacterial Enzyme Activity," The American Journal of Clinical Nutrition, Vol. 39, 1984, pp. 756-761.

[11] C. V. Rao, M. E. Sanders, C. Indranine, B. Simi and B. S. Reddy, "Preservation of Colonic Preneoplastic Lesions by the Probiotic Lactobacillus acidophilus NCFMTM in F344 Rats,” International Journal of Oncology, Vol. 14, 1999, p. 939.

[12] R. Hutkins, "Probiotics and Health to Drive US Yogurt Market,” 2006. http://www.foodnavigator-usa.com/Financial-Industry/Pr obiotics-and-health-to-drive-US-yogurt-market

[13] F. V. Kosikowski, “Cheese and Fermented Milk Foods,” 2nd Edition, Edwards Brothers, Inc., Ithaca, 1982.

[14] K. J. Aryana, "Folic Acid Fortified Fat Free Plain Set Yogurts,” International Journal of Dairy Technology, Vol. 56, No. 4, 2003, pp. 219-222. doi:10.1046/j.1471-0307.2003.00105.x

[15] K. J. Aryana, S., Pluche, R. M. Rao, P. McGrew and N. P. Shah, "Fat Free Plain Yogurt Manufactured with Inulins of Various Chain Lengths and Lactobacillus acidophilus," Journal of Food Science, Vol. 72, No. 3, 2007, pp. M79-M84. doi:10.1111/j.1750-3841.2007.00302.x

[16] W. E. V. Lankaputhra, N. P. Shah and M. L. Britz, "Survival of Bifidobacteria during Refrigerated Storage in the Presence of Acid and Hydrogen Peroxide," Milchwissenschaft, Vol. 51, No. 2, 1996, pp. 65-70. 